\title{
Effect of Health Education Intervention on Knowledge, and attitude regarding Menopausal Period among Premenopausal Female Employees
}

\author{
Eman E. Orabi
}

Public health and community medicine department-Zagazig University-Egypt

Received: July 2016 Accepted: September 2016

\begin{abstract}
Background: The menopausal transition is a critical period in women's life; many physiological changes occur and cause morbidity to women at this stage. Women generally know very little about menopause, therefore, they should have knowledge about menopause. Objectives: to evaluate the effect of a health education program addressing the general health of menopausal women. Participants and method: An interventional study was carried out on 80 premenopausal female employees aged from 40 to 45 years at $10^{\text {th }}$ of Ramadan city schools by comparing pre-intervention with post-intervention questionnaire after a health education program which included questions to assess knowledge and attitude about menopause. Results: there were statistically significant improvement of knowledge and attitude after the interventional program that corrected knowledge: being $51.3 \%$ among studied participants before the educational program and improved to $88.8 \%$ after the program and a positive attitude that changes from $6.3 \%$ before the program to $90 \%$ after the program. Conclusion and recommendation: This study concluded that health education about menopause improved knowledge and attitude of the studied women, so health education programs directed to menopause women need to be integrated within health care system.
\end{abstract}

Key words: health education-menopause-female employees-coping requirement

Corresponding author, Email: - dr.eman.elshahat@gmail.com

\section{Introduction}

Menopause is the time in a woman's life when her period stops. It usually occurs naturally, most often after age 45years. Menopause happens because the woman's ovaries stop producing the hormones estrogen and progesterone. A woman has reached menopause when she has not had a period for one year. ${ }^{1}$ The mean age of the menopause in Egypt is 46.7 years, which is low compared to many countries, but this age has been rising recently. The incidence of menopause-associated symptoms in Egyptian women is higher than in the West, probably because of the different sociocultural attitudes towards the menopause in different communities. ${ }^{2}$ The cultural context within which a woman lives can have a significant impact on the way she experiences the menopausal transition. Menopause has been described as a subjective experience, social and cultural factors playing a prominent role in the way menopause is experienced and perceived. ${ }^{3}$ Changes and symptoms of menopause include a change in periods, hot flashes and/or night sweats, trouble sleeping, vaginal dryness, mood swings, trouble focusing and less hair on head, more on face. Some symptoms require treatment. The doctor should ask about medical and family history to know risks for heart disease, osteoporosis, or breast cancer. ${ }^{1}$ Many women cope with mild- menopausal symptoms and don't 
need to take any medication or use therapies. Some women manage their symptoms well with lifestyle measures like eating well and getting regular physical activity. Other women with symptoms that are affecting their quality of life will need to seek treatment. Coping with menopause symptoms can be helped by healthy eating, a balanced nutritious diet, exercise and relaxation. Women, who try to make their lifestyle as healthy as they can, appear to have less menopause symptoms and those symptoms are less severe. ${ }^{4}$ Health education is any combination of learning experiences designed to help individuals and communities improve their health, by increasing their knowledge or influencing their attitudes. ${ }^{5}$

\section{Participants and methods}

\section{I-Technical design:}

Research setting \& time: $10^{\text {th }}$ of Ramadan city schools. The study was carried out during the period from March 2015 to October 2015.

Sample size: The sample size was calculated using Epi-info software (version 6.04) ${ }^{6}$, assuming that the prevalence of women knowledge and attitude is $48.6 \%{ }^{7}$ at $95 \%$ confidence interval and power of $80 \%$. We assumed that health education will change the knowledge or attitude to $80 \%$, the calculated sample size was 80 females, to be taken randomly from females (40-45 years) working in $10^{\text {th }}$ of Ramadan city schools

Sampling technique: A multi stage sampling method.

First stage: A simple random sampling for selected school: Three schools were selected randomly from all $10^{\text {th }}$ of Ramadan city public and private schools $\left(10^{\text {th }}\right.$ of Ramadan public school, Future formal public school and New vision private schools). Each one of these schools has primary, preparatory and secondary schools.

Second stage: A simple random sample technique within each selected school for premenopausal female employees after their division into three category teachers, administrators and workers then select randomly the desired number from premenopausal female employees taking in consideration the relative proportion of female employees in each category.

Inclusion criteria: Premenopausal women (40-45 years) working in the selected $10^{\text {th }}$ of Ramadan City Schools still having menstruation (suffering from premenopausal symptoms).

\section{II-Operational design which includes} the following:

A-Pilot study: Done on a number of women equal to $10 \%$ of calculated sample of females aged (40-45 years). It is used to test the questionnaire with the most appropriate terms. It also helped to estimate time needed for data collection and detect the obstacles of the study but they excluded from the main sample because of changes that done in the final version of the tools.

B-Data collection and field work:Data were collected via personal interview with the premenopausal females. A questionnaire sheet was designed to assess knowledge and attitude of women towards menopause including the following data: (1) Socio demographic characteristics of premenopausal women and their husband e.g age, residence, educational level, occupation ...etc. Socio-economic class: was calculated from the women educational level, occupation, husband education level, husband occupation, crowding index and family income, by a modified method of El-Sherbini and Fahmy. ${ }^{14}$ (2) Questions to assess knowledge about menopause:knowledge about Definition of menopause, Hot flushes, Heart problem , Weight gain, Mood changes, Menses changes, Osteoporosis, Insomnia and irritability, Dyspareunia, Urinary incontinence and hormonal replacement therapy (HRT). (3) Questions to assess attitudes, of women toward menopause: Considering it natural aging, Counsel a 
doctor, Effect on health, Effect on sexual life, Effect on family, Effect on work colleagues and Attitude toward HRT

Intervention: It was a health education intervention program for the studied premenopausal women to increase their knowledge about menopause and correct their wrong attitude about it.

(a) Message: The studied women were given 6 educational sessions to cover knowledge and improve attitude toward menopause its main items cover definition of menopause, the age of menopause, health problems with menopause and their causes, how to deal with menopause through life style changes and notes on hormone replacement therapy.

(b) Methods: Group discussions in addition, the use of teachings aids, such as posters helped to enrich and facilitate the educational process.

(c) Time: Each educational session lasted about 45 minutes and the whole course of intervention stage lasted for about two months.

Evaluation (post-test): Two months later after implementing the health education sessions, all studied women were asked to complete a questionnaire form which was the same as that used in the pre test.

Scoring of knowledge and attitude: Questions with yes or no answer were scored as follows: Yes $=1$ and No $=$ zero. Questions with open answers were scored as follows: Don't know = zero, know incomplete answer $=1$ and complete answer $=2$. Questions with various answers were scored as follows: every answer took a degree from 0 to 4 ( bad attitude $=0$ and good attitude $=4$ ). Total score of all items of knowledge about menopause was 12 degrees and total score of all items of attitude about menopause was 28 degrees

Adequacy of knowledge and attitude was considered as follows: Score of $60 \%$ or more was considered satisfactory. Score less than $60 \%$ of total score was considered unsatisfactory score.

Administrative design: This study was carried out under supervision of community medicine department and Intramural Research Program Committee of faculty of medicine, Zagazig University. An official permission was obtained from $10^{\text {th }}$ of Ramadan educational Directorate. An official permission was obtained from school managers of selected school.

Ethical considerations: An informed written consent was obtained from every studied woman before filling the questionnaire. Confidentiality of the data was insured.

Data management: Data was analyzed using statistical package of social sciences (SPSS) version 20. Qualitative data were presented as frequencies and percent and McNemar's Chi- squared test was used to test significance of change for post intervention versus pre intervention. The results were considered statistically significant when probability (p) is equal or less than 0.05 .

\section{Results}

Table (1): Socio-demographic characteristics of the studied premenopausal women and their husband.This table shows that the mean age of the studied women are 42.7 years, $57.5 \%$ of them coming from rural areas, $53.7 \%$ are highly educated and teachers, $46.2 \%$ of them their husbands were highly educated also $62.5 \%$ of them were employees, $53.7 \%$ of them had enough income and $56.3 \%$ of them were in moderate socioeconomic status. All of the studied women were married.

Table (2): women knowledge parameters about menopause before and after the intervention program. (Table 2). Before intervention, the least level of knowledge was for knowledge about urinary incontinence $(2.5 \%)$ and dyspareunia (3.8\%). -Knowledge about HRT was high (52.5\%) before 
intervention, probably as HRT is to some extent covered by the media and it is easy to be understood by these women because most of them were highly educated. The highest improvement was for knowledge about Insomnia and irritability that had increased from $11.3 \%$ before intervention to $88.8 \%$ after intervention, mode changes that had increased from $30 \%$ before intervention to $91.3 \%$ after intervention, knowledge about associated heart problems with menopause had increased from 51.3\% before intervention to $92.5 \%$ after intervention followed by knowledge about osteoporosis had increased from $52.5 \%$ before intervention to $90 \%$ after intervention and Definition of menopause had increased from 51.3\% before intervention to $90 \%$ after intervention. Other knowledge parameters were improved after the intervention but improvement was less than previous parameters. Table (3): Women attitude parameters about menopause before and after the intervention program. The table shows significant improvement in all attitude parameters after intervention. The highest percent of improvement is for counseling a doctor which changed from $7.5 \%$ to $90 \%$.There is significant improvement in total attitude about menopause after intervention. Table (4): The relation of sociodemographic characteristics of women and their husbands and knowledge before and after intervention. This table shows that there is statistically significant improvement in knowledge of low educated women and workers after intervention which increased from 9\% before intervention to $91 \%$ after intervention and there is statistically significant improvement in knowledge of women's whose husbands are low educated (illiterate, read \& write) from $18.2 \%$ before intervention to $90.9 \%$ after intervention . Also, women's whose husbands are farmers or unskilled workers shows statistically significant improvement in knowledge from 11.1 before intervention to $88.9 \%$ after intervention. Also, there is statistically significant improvement in knowledge of low socioeconomic state women from $31.6 \%$ before intervention to $94.7 \%$ after intervention. While, there is no statistically significant association between satisfactory knowledge, income.

Table (5): The relation between attitude and sociodemographic characteristics of women and their husbands and knowledge before and after intervention. This table shows that there is none statistically significant difference between residence, educational level, occupation of women and their husbands, income, socioeconomic level and attitude before and after intervention.

\section{Discussion}

The transition to menopause is an important period in the female life that is associated with variable physical and psychological symptoms. Physicians should be prepared to provide education about the menopause. Physicians also should be well-trained to educate and encourage perimenopausal women to initiate lifestyle changes that can enhance their health for the rest of their lives.

Knowledge about menopause:
Regarding women rnowledge
parameters about menopause before
and after the intervention program.
(Table 2). Before intervention, the least level of knowledge was for knowledge about urinary incontinence $(2.5 \%)$ and dyspareunia (3.8\%). This may be due to these items are usually shameful; so, they are rarely covered by the media and women rarely discuss these items with health care providers or with other people. Knowledge about HRT was high $(52.5 \%)$ before intervention, probably as HRT is to some extent covered by the media and it is easy to be understood by these women because most of them were 
highly educated. The highest improvement was for knowledge about Insomnia and irritability that had increased from $11.3 \%$ before intervention to $88.8 \%$ after intervention, mode changes that had increased from $30 \%$ before intervention to $91.3 \%$ after intervention. Other knowledge parameters were improved after the intervention but improvement was less than previous parameters. This variation in improvement level from one parameter to another may be explained by that, women were more interested to know about these issues (Insomnia and irritability, mood problems, heart problems and osteoporosis) than others like urinary incontinence and also that the educational program might give women more details or was more clear and easy to be understood in these points. This variation was in agreement with another study conducted in Egypt by Mahmoud et al and Salem 7,8 who revealed that there were significant improvements in different knowledge parameters after the program with variation in improvement level from one knowledge parameter to another. Regarding the total knowledge (Table 2) it was found that total satisfactory knowledge was $51.3 \%$ before intervention which improved to be $88.8 \%$ after the intervention program and these results were in agreement with Mahmoud et al ${ }^{7}$ which concluded that their total correct knowledge was $48.6 \%$ before intervention and improved to 99.3\% after their intervention program. However, the results of the present study are higher than the results reported in other studies. Hassan ${ }^{9}$ found that $14.4 \%$ of women had correct knowledge about menopause before intervention and improved to be $68.9 \%$ after a health education program. Salem ${ }^{8}$ found that $21.7 \%$ of women had correct knowledge about menopause and improved to $82.6 \%$ after the program. Yasmin et $\mathbf{a l}^{10}$ reported that $27.8 \%$ of women had correct knowledge which improved to become $49.3 \%$ after the health education program. According to previous studies, it is evident that health education plays an important role in improving information of women about menopause. Regarding the association between sociodemographic characteristics and total knowledge. This study found that residence of women had no significant effect on improvement of knowledge about menopause after the intervention (Table 4). This result is similar to another study Chen Richardson et al ${ }^{11}$ who mentioned that residence did not affect improvement of knowledge and explained that as women when having a good available source of knowledge about menopause, their knowledge improved regardless of their residence. The media and other sources of information are now available for all ages in both urban and rural areas. Also, it was in agreement with Mahmoud et $\mathbf{a l}^{7}$ who concluded that residence of women had no significant effect on improvement of knowledge about menopause after the intervention. Regarding the educational level (Table 4), the improvement in knowledge was significantly higher in illiterate and those who read \& write $(91 \%)$ than secondary and highly educated women $(76.9 \%$ and $74.4 \%$ respectively). This may be attributed to that highly educated women had more information about menopause before the intervention than women of other educational levels; so after the program, change was more obvious in lower educational level (illiterate, read \&write). This was to some extent similar to the study done by Mahmoud et al $^{7}$ who concluded that the improvement in knowledge was significantly higher in essentially educated and illiterate and read \&writes women $(66.7 \%$ and $53.0 \%$, respectively) than secondary and highly educated women who had lower satisfying change $(31.1 \%)$. However, this result is 
contradicted to Salem ${ }^{8}$, who found that the improvement in knowledge after the educational program was higher among secondary and highly educated women than lower educational levels and attributed this to the more awareness and easier communication of secondary and higher educated women. Regarding the occupational status of the women (Table 4), this study showed that the improvement in knowledge was significantly higher among workers (91\%) than among teachers (74.4\%). This can be attributed to that working women may have more information because they communicate with different people from different levels, so the improvement after the program was more in workers who had little information from the start. This result was to some extent similar to the study done by Mahmoud et al $^{7}$ who showed that the improvement in knowledge was significantly higher among workers $(51.5 \%)$ than among professional women (29.3\%). This result is contradicted to the results of other studies done by Salem ${ }^{8}$ and Brand and Lehert ${ }^{12}$, who found that improvement in knowledge was more in professional women than in workers and attributed this to more awareness and easier communication of professional women than workers. Regarding the educational level and work of husbands of the studied women (Table 4), the improvement in knowledge significantly increased with the decrease in educational level of husband and it was higher among women whose husbands were unskilled workers or not working. This may be attributed to that women of secondary and highly educated husbands as well as women of employees and skilled workers had more information about menopause before the intervention than women of other educational or work levels of husbands as living with educated and more oriented people is usually reflected on other family members. So after the program improvement was more obvious in lower educational and work levels that had lower knowledge from the start. This result was to some extent similar to the study done by Mahmoud et al ${ }^{7}$. Family income had no statistically significant effect on improvement of knowledge when studied alone (Table 4), but when the socioeconomic level is studied as a whole, this study showed that improvement of knowledge was significantly higher among people of low socioeconomic level than people of moderate and low socioeconomic levels (Table 4). Again, this may be attributed to higher awareness and higher baseline data of higher socioeconomic levels from the start. This result was in agreement with the study done by Mahmoud et al $^{7}$ However, this result is in contrast to the result of Salem $^{8}$ who mentioned that improvement of knowledge was significantly higher among people of high socioeconomic level than people of lower socioeconomic levels. Attitude about menopause: The present study showed that there is a significant improvement in attitude after the program (Table 3). This result may be explained by that, when people have a good knowledge about menopause and its health problems and how to deal with it, they have more positive attitude towards it. This result was in agreement with other studies Salem ${ }^{8}$ and Mahmoud et al $^{7}$ which showed that there was significant improvement in attitude after the health education program. As regard the total attitude (Table 3), it was found that total positive attitude toward menopause was $6.3 \%$ before the intervention which improved to be $90 \%$ after the intervention. This improvement in attitude was higher than the results of Salem ${ }^{8}$ who stated that only $6.3 \%$ of the studied women had positive attitude toward menopause before intervention and changed to be $90 \%$ after the program. This result was also, in agreement with the study done by 
Mahmoud et al $^{7}$ who showed that total positive attitude toward menopause was $4.2 \%$ before the intervention which improved to be $59 \%$ after the intervention. However it was different from Hassan ${ }^{9}$ who mentioned that about $23.3 \%$ of women had positive attitude toward menopause and changed to be $46.7 \%$ after the program. Olofsson and Collins $^{13}$ found that $30 \%$ of Swedish women had positive attitude toward menopause and improved to be $70 \%$ after a health education program. These differences may be attributed to the differences in the communities, and degree of orientation of women about menopause. Regarding the association between sociodemographic characteristics and total attitude. the present study showed that there is no significant relation between improvement of attitude and residence of women; so, change of attitude is nearly similar in both urban and rural women (Table 5). This is also expected as the residence did not affect the level of knowledge of the studied women (Table 5). This result is similar to another study Chen Richardson et al $^{11}$ which mentioned that residence did not affect improvement of attitude and explained that women with good knowledge were more liable to have positive attitude toward menopause regardless of their residence. This result was also, in agreement with the study done by Mahmoud et al $^{7}$ who showed that residence did not affect improvement of attitude. Regarding the education and the work of women, the present study showed that there is no significant relation between improvement of attitude and the education and the work of women (Table 5). This result was in agreement with the study done by Mahmoud et al $^{7}$ who revealed that education and the work of women did not affect improvement of attitude. As regard the income and the socioeconomic level of women, the present study showed that there is no significant relation between improvement of attitude and income and socioeconomic level of women (Table 5) This result was in agreement with the study done by Mahmoud et al $^{7}$ who showed that income and socioeconomic level of women did not affect improvement of attitude.

\section{Recommendations}

Menopause needs to be on public health agenda. Health education programs for women about menopause need to be integrated within health care system. Proper training of health care providers so as to understand the variability, consequences, and treatment modalities of this time. Further studies are recommended for assessment of health problems associated with menopause for better estimation of this problem.

\section{References}

1. Dept. of Health and Human Services Office on Women's Health: The Menopause Years and Beyond. Available on (2015) http://www.nlm.nih.gov/ medlineplus/menopause.htmlThe

Menopause Years and Beyond

2. Sallam H., Galal A., Rashed A. Finset A. and Markides K.: Menopause in Egypt: past and present perspectives. Climacteric.; (2006)9(6):421-9.

3. Winterich, J.: Gender, medicine, and the menopausal body: How biology and culture influence women's experiences with menopause". Paper presented at the annual meeting of the American Sociological Association, New York. Retrieved November 11, 2008 from Allacademic.com

4. Hailes S.: Menopause management. Available on (2014) http://jeanhailes.org. au/health-a-z/menopause/menopause-

management

5. WHO (World Health Organization), health education . Available on (2015) http://www.who.int/topics/health_educati on/en/

6. Dean A., Dean J., Coulombeir B. and Brendel B. :Epi-info version 6: a 
word processing data base and statistics program for epidemiology on microcomputers. (1994) Center for Disease Control. Atlanta, Georgia, USA.

7. Mahmoud H., Elnagar S., Mohamed A. :-Health education program effect on knowledge and attitude of perimenopausal and menopausal women toward menopause at El-Arbaien district in Suez Governorate. Master thesis (2013) of family medicine -Zagazig University.

8. Salem M.: Impact of an educational program about menopause to menopause menopausal women on their knowledge, attitude, practice, family function and quality of life in Abou-Khalifa village Ismailia Governorate. M.D thesis (2003) in family medicine. Suez canal university.

9. Hassan A.:- Assessment of knowledge and attitude towards menopause the Egyptian Journal of community medicine(2006); 22:61-64.

10. Yasmin C., Hillis S., Jamieson

D., Zirilli L. and Granata A., et al.:-
Assessment of knowledge and attitude towards menopause the Egyptian Journal of community medicine (2009); 22:6164.

11. Chen Richardson K., Moehrer B., Hextall A., and Glazener C.:- Impact of an educational program about menopause to menopause menopausal women on their knowledge, attitude, practice, family function and quality of life. Climacteric ( 1998); 3(1):23-32

12. Brand P. and Lehert P.: A prospective study of factors affecting age at menopause". J. Clin. Epidemiol. (1998), 42(11):1030-1039.

13. Olofsson A. and Collins A. : Psychological factors, attitude to menopause and symptom36 $\mathrm{KBs}$ in Swedish perimenopausal women. Climacteric (2000); 3(1):33-42.

14. El - Sherbini A. and Fahmy B.: determining simple parameters for social classification for health researcher. Bulletin of the high institute of public health (1983); 235:1-14. 
Table (1): Socio-demographic characteristics of the studied pre-menopausal women and their husband.

\begin{tabular}{|c|c|c|}
\hline Characteristics & $\begin{array}{l}\text { Frequency } \\
(\text { No. }=80)\end{array}$ & $\begin{array}{c}\text { Percent } \\
(\%)\end{array}$ \\
\hline $\begin{array}{l}\text { Age (years): } \\
\text { Mean } \pm \text { SD }\end{array}$ & $42.7 \pm 1.9$ & Range (40-45 y) \\
\hline $\begin{array}{l}\text { Residence } \\
\text { Rural } \\
\text { Urban }\end{array}$ & $\begin{array}{l}46 \\
34 \\
\end{array}$ & $\begin{array}{l}57.5 \\
42.5 \\
\end{array}$ \\
\hline $\begin{array}{l}\text { Educational status } \\
\text { Illiterate } \\
\text { Read \& write } \\
\text { Secondary } \\
\text { Highly educated } \\
\end{array}$ & $\begin{array}{r}4 \\
7 \\
26 \\
43\end{array}$ & $\begin{array}{r}5.0 \\
8.8 \\
32.5 \\
53.7\end{array}$ \\
\hline $\begin{array}{l}\text { Current job } \\
\text { workers } \\
\text { adminestrators } \\
\text { Teachers }\end{array}$ & $\begin{array}{l}11 \\
26 \\
43\end{array}$ & $\begin{array}{l}13.8 \\
32.5 \\
53.7\end{array}$ \\
\hline $\begin{array}{l}\text { Husband education } \\
\text { Illiterate } \\
\text { Read \& write } \\
\text { Secondary } \\
\text { University education and above }\end{array}$ & $\begin{array}{r}5 \\
6 \\
32 \\
37\end{array}$ & $\begin{array}{r}6.3 \\
7.5 \\
40.0 \\
46.2\end{array}$ \\
\hline $\begin{array}{l}\text { Husband job: } \\
\text { Not working } \\
\text { unskilled worker } \\
\text { Skilled worker } \\
\text { Employee }\end{array}$ & $\begin{array}{r}6 \\
9 \\
15 \\
50\end{array}$ & $\begin{array}{r}7.5 \\
11.3 \\
18.8 \\
62.5\end{array}$ \\
\hline $\begin{array}{l}\text { Income } \\
\text { Enough } \\
\text { Not enough }\end{array}$ & $\begin{array}{l}43 \\
37\end{array}$ & $\begin{array}{l}53.7 \\
46.3\end{array}$ \\
\hline $\begin{array}{l}\text { Socioeconomic } \\
\text { Low } \\
\text { Moderate } \\
\text { High }\end{array}$ & $\begin{array}{l}19 \\
45 \\
16\end{array}$ & $\begin{array}{l}23.8 \\
56.3 \\
20.0\end{array}$ \\
\hline
\end{tabular}


Table (2): Women knowledge parameters about menopause before and after the intervention program.

\begin{tabular}{|c|c|c|c|c|c|}
\hline \multirow{3}{*}{$\begin{array}{l}\text { Knowledge } \\
\text { Parameters }\end{array}$} & \multirow{2}{*}{\multicolumn{2}{|c|}{$\begin{array}{c}\text { Before } \\
\text { intervention } \\
(\text { No.=80) }\end{array}$}} & \multirow{2}{*}{\multicolumn{2}{|c|}{$\begin{array}{c}\text { After } \\
\begin{array}{c}\text { Intervention } \\
(\text { No.=80) }\end{array} \\
\text { correct }\end{array}$}} & \multirow{3}{*}{ P-Value } \\
\hline & & & & & \\
\hline & No & $\%$ & No & $\%$ & \\
\hline Definition of menopause & 41 & 51.3 & 72 & 90.0 & $<0.001$ \\
\hline Hot flushes & 42 & 52.5 & 71 & 88.8 & $<0.001$ \\
\hline Heart problem & 41 & 51.3 & 74 & 92.5 & $<0.001$ \\
\hline Weight gain & 42 & 52.5 & 71 & 88.8 & $<0.001$ \\
\hline Mood changes & 24 & 30.0 & 73 & 91.3 & $<0.001$ \\
\hline Menses changes & 41 & 51.3 & 44 & 55.0 & $<0.001$ \\
\hline Osteoporosis & 42 & 52.5 & 72 & 90.0 & $<0.001$ \\
\hline Insomnia and irritability & 9 & 11.3 & 71 & 88.8 & $<0.001$ \\
\hline Dyspareunia & 3 & 3.8 & 47 & 58.8 & $<0.001$ \\
\hline Urinary incontinence & 2 & 2.5 & 41 & 51.3 & $<0.001$ \\
\hline Knowledge about HRT $*$ & 25 & 31.3 & 44 & 55.0 & $<0.001$ \\
\hline Total Knowledge & 41 & 51.3 & 71 & 88.8 & $<0.001$ \\
\hline
\end{tabular}

*HRT= hormonal replacement therapy \& p-value of McNemar Chi-Square test 
Table (3): Women attitude parameters about menopause before and after the intervention program.

\begin{tabular}{|c|c|c|c|c|c|}
\hline \multirow[t]{3}{*}{ Attitude parameter } & \multirow{2}{*}{\multicolumn{2}{|c|}{$\begin{array}{c}\begin{array}{c}\text { Before } \\
\text { intervention } \\
(\mathbf{n}=\mathbf{8 0})\end{array} \\
\text { Positive }\end{array}$}} & \multirow{2}{*}{\multicolumn{2}{|c|}{$\begin{array}{c}\begin{array}{c}\text { After } \\
\text { intervention } \\
(\mathbf{n}=80)\end{array} \\
\text { Positive }\end{array}$}} & \multirow[t]{3}{*}{ p-value } \\
\hline & & & & & \\
\hline & No & $\%$ & No & $\%$ & \\
\hline Consider it natural aging & 52 & 65.0 & 76 & 95.0 & $<0.001$ \\
\hline Counsel a doctor & 6 & 7.5 & 72 & 90.0 & $<0.001$ \\
\hline Effect on health & 2 & 2.5 & 73 & 91.3 & $<0.001$ \\
\hline Effect on sexual life & 5 & 6.3 & 72 & 90.0 & $<0.001$ \\
\hline Effect on family & 11 & 13.8 & 74 & 92.5 & $<0.001$ \\
\hline Effect on work colleagues & 6 & 7.5 & 41 & 51.3 & $<0.001$ \\
\hline Attitude toward HRT & 2 & 2.5 & 42 & 52.5 & $<0.001$ \\
\hline Total attitude & 5 & 6.3 & 72 & 90.0 & $<0.001$ \\
\hline
\end{tabular}

p.value of McNemar Chi-Square test 
Table (4): The relation between knowledge before and after intervention and sociodemographic characteristics of the studied premenopausal women and their husbands.

\begin{tabular}{|c|c|c|c|c|c|}
\hline & \multicolumn{4}{|c|}{ Knowledge } & \multirow{4}{*}{ P-Value } \\
\hline & \multirow{2}{*}{\multicolumn{2}{|c|}{$\begin{array}{c}\begin{array}{c}\text { Before } \\
\text { intervention } \\
(\mathrm{N}=80)\end{array} \\
\text { Correct } \\
\end{array}$}} & \multirow{2}{*}{\multicolumn{2}{|c|}{$\begin{array}{c}\begin{array}{c}\text { After } \\
\text { intervention } \\
(\mathbf{N}=\mathbf{8 0})\end{array} \\
\text { Correct } \\
\end{array}$}} & \\
\hline & & & & & \\
\hline & No & $\%$ & No & $\%$ & \\
\hline $\begin{array}{l}\text { Residence } \\
\text { Rural }(\mathrm{N}=46) \\
\text { Urban }(\mathrm{N}=34)\end{array}$ & $\begin{array}{l}20 \\
15\end{array}$ & $\begin{array}{l}43.5 \\
44.1\end{array}$ & $\begin{array}{l}26 \\
19\end{array}$ & $\begin{array}{l}56.5 \\
55.9\end{array}$ & 0.273 \\
\hline $\begin{array}{l}\text { Women Educational level: } \\
\text { Illiterate and read \& write }(\mathrm{N}=11) \\
\text { Secondary }(\mathrm{N}=26) \\
\text { Higher }(\mathrm{N}=43)\end{array}$ & $\begin{array}{r}1 \\
6 \\
21\end{array}$ & $\begin{array}{r}9.0 \\
23.1 \\
48.8\end{array}$ & $\begin{array}{l}10 \\
20 \\
32\end{array}$ & $\begin{array}{l}91.0 \\
76.9 \\
74.4\end{array}$ & $\begin{array}{l}<0.001 \\
<0.001 \\
0.015\end{array}$ \\
\hline $\begin{array}{l}\text { Women Occupational level: } \\
\text { Workers }(\mathrm{N}=11) \\
\text { Administrators }(\mathrm{N}=26) \\
\text { Teachers }(\mathrm{N}=43)\end{array}$ & $\begin{array}{r}1 \\
6 \\
21 \\
\end{array}$ & $\begin{array}{r}9.0 \\
23.1 \\
48.8 \\
\end{array}$ & $\begin{array}{l}10 \\
20 \\
32 \\
\end{array}$ & $\begin{array}{l}91.0 \\
76.9 \\
74.4 \\
\end{array}$ & $\begin{array}{l}<0.001 \\
<0.001 \\
0.015\end{array}$ \\
\hline $\begin{array}{l}\text { Husband Educational level: } \\
\text { Illiterate and read \& write }(\mathrm{N}=11) \\
\text { Secondary }(\mathrm{N}=32) \\
\text { Higher }(\mathrm{N}=37)\end{array}$ & $\begin{array}{r}2 \\
15 \\
19 \\
\end{array}$ & $\begin{array}{l}18.2 \\
46.9 \\
51.4 \\
\end{array}$ & $\begin{array}{l}10 \\
25 \\
28 \\
\end{array}$ & $\begin{array}{l}90.9 \\
78.1 \\
75.6 \\
\end{array}$ & $\begin{array}{l}<0.001 \\
0.009 \\
0.029 \\
\end{array}$ \\
\hline $\begin{array}{l}\text { Husband Work: } \\
\text { Not working }(\mathrm{N}=6) \\
\text { Farmer \& unskilled worker }(\mathrm{N}=9) \\
\text { Skilled worker }(\mathrm{N}=15) \\
\text { Employee }(\mathrm{N}=50) \\
\end{array}$ & $\begin{array}{r}3 \\
1 \\
5 \\
23\end{array}$ & $\begin{array}{l}50.0 \\
11.1 \\
33.3 \\
64.0 \\
\end{array}$ & $\begin{array}{r}3 \\
8 \\
11 \\
34 \\
\end{array}$ & $\begin{array}{l}50.0 \\
88.9 \\
73.3 \\
68.0\end{array}$ & $\begin{array}{l}1.0 \\
<0.001 \\
0.028 \\
0.026\end{array}$ \\
\hline $\begin{array}{l}\text { Income } \\
\text { Not enough }(\mathrm{N}=37) \\
\text { Enough }(\mathrm{N}=43)\end{array}$ & $\begin{array}{l}17 \\
21 \\
\end{array}$ & $\begin{array}{l}45.9 \\
48.8 \\
\end{array}$ & $\begin{array}{l}25 \\
27 \\
\end{array}$ & $\begin{array}{l}67.6 \\
62.8 \\
\end{array}$ & 0.753 \\
\hline $\begin{array}{l}\text { Socioeconomic level } \\
\text { Low }(\mathrm{N}=19) \\
\text { Moderate }(\mathrm{N}=45) \\
\text { High }(\mathrm{N}=16)\end{array}$ & $\begin{array}{r}5 \\
21 \\
6\end{array}$ & $\begin{array}{l}31.6 \\
51.1 \\
37.5\end{array}$ & $\begin{array}{l}18 \\
35 \\
12\end{array}$ & $\begin{array}{l}94.7 \\
77.8 \\
75.0\end{array}$ & $\begin{array}{l}<0.001 \\
0.002 \\
0.032\end{array}$ \\
\hline
\end{tabular}

p-value of McNemar Chi-Square test 
Table (5): The relation between attitude before and after intervention and sociodemographic characteristics of the studied premenopausal women and their husbands.

\begin{tabular}{|c|c|c|c|c|c|}
\hline \multirow{4}{*}{ Parameter } & \multicolumn{4}{|c|}{ Attitude } & \multirow{4}{*}{ *P-Value } \\
\hline & \multirow{2}{*}{\multicolumn{2}{|c|}{$\begin{array}{c}\begin{array}{c}\text { Before } \\
\text { intervention } \\
(\text { No.=80) }\end{array} \\
\text { Positive } \\
\end{array}$}} & \multicolumn{2}{|c|}{$\begin{array}{l}\text { After intervention } \\
\qquad(\text { No. }=80)\end{array}$} & \\
\hline & & & \multicolumn{2}{|c|}{ Positive } & \\
\hline & No. & $\%$ & No. & $\%$ & \\
\hline Residence: & & & & & \\
\hline Rural (N=46) & 7 & 15.2 & 39 & 84.8 & 0.771 \\
\hline Urban $(\mathrm{N}=34)$ & 6 & 17.6 & 28 & 82.4 & \\
\hline Educational level: & & & & & \\
\hline Illiterate and read \& write $(\mathrm{N}=11)$ & 2 & 18.2 & 6 & 54.5 & 0.076 \\
\hline Secondary $(\mathrm{N}=26)$ & 6 & 23.1 & 11 & 42.3 & 0.139 \\
\hline Higher $(\mathrm{N}=43)$ & 22 & 51.1 & 28 & 65.1 & 0.189 \\
\hline Occupational level: & & & & & \\
\hline Workers $(\mathrm{N}=11)$ & 2 & 18.2 & 6 & 54.5 & 0.076 \\
\hline Administrators $(\mathrm{N}=26)$ & 6 & 23.1 & 11 & 42.3 & 0.139 \\
\hline Teachers $(\mathrm{N}=43)$ & 22 & 51.1 & 28 & 65.1 & 0.189 \\
\hline Educational level: & & & & & \\
\hline Illiterate and read \& write $(\mathrm{N}=11)$ & 3 & 27.3 & 7 & 63.6 & 0.086 \\
\hline Secondary $(\mathrm{N}=32)$ & 14 & 43.8 & 19 & 59.4 & 0.211 \\
\hline Higher $(\mathrm{N}=37)$ & 20 & 54.1 & 27 & 73.0 & 0.09 \\
\hline Work: & & & & & \\
\hline Not working $(\mathrm{N}=6)$ & 2 & 33.3 & 4 & 66.6 & 0.248 \\
\hline Farmer \& unskilled worker $(\mathrm{N}=9)$ & 4 & 44.4 & 7 & 77.8 & 0.146 \\
\hline Skilled worker $(\mathrm{N}=15)$ & 9 & 60.0 & 12 & 80.0 & 0.231 \\
\hline Employee $(\mathrm{N}=50)$ & 27 & 54.0 & 35 & 70.0 & 0.099 \\
\hline Income & & & & & \\
\hline Not enough $(\mathrm{N}=37)$ & 7 & 18.9 & 30 & 81.1 & 0.548 \\
\hline Enough $(\mathrm{N}=43)$ & 6 & 14.0 & 37 & 86.0 & \\
\hline Socioeconomic level & & & & & \\
\hline Low $(\mathrm{N}=19)$ & 12 & 15.8 & 16 & 84.2 & 0.141 \\
\hline Moderate $(\mathrm{N}=45)$ & 27 & 15.6 & 34 & 84.4 & 0.114 \\
\hline $\operatorname{High}(\mathrm{N}=16)$ & 10 & 18.8 & 14 & 81.2 & 0.102 \\
\hline
\end{tabular}

p-value of McNemar Chi-Square test 